\title{
Analysis of Entrepreneurial Orientation and Education Level of the MSMEs Actors in Improving MSMEs Performance in Bengkalis Regency
}

\author{
Desmiyawati $^{1^{*}} \quad$ Amries Rusli Tanjung $^{2} \quad$ Nur Azlina $^{1} \quad$ Yesi Mutia Basri $^{1} \quad$ Sri Indrastuty S. ${ }^{3}$ \\ 1.Lecturer at the Faculty of Economics and Business, University of Riau, \\ Binawidya Campus KM.12.5 SimpangBaru, Tampan,Pekanbaru, Riau, 28296 \\ 2.Professor at the Faculty of Economics and Business, University of Riau, \\ Binawidya Campus KM.12.5 SimpangBaru, Tampan, Pekanbaru, Riau, 28296 \\ 3.Professor at the Faculty of Economics and Business, Universitas Islam Riau, \\ KaharuddinNst, SimpangTiga, Bukit Raya, Pekanbaru, Riau, 28284
}

\begin{abstract}
This research was aimed at identifying factors that affected the MSMEs performance in Bengkalis Regency, Riau Province. The research population was all MSMEs in Bengkalis Regency which amounted to 42,029 MSMEs, while the samples were 100 MSMEs selected using Slovin formula. The data occupied were primary data where the respondents were given a questionnaire/written questions regarding MSMEs performance, entrepreneurial orientation (proactiveness, innovativeness, and risk taking) and education level of MSMEs actors. Analyzing the data was done using multiple regression to find out the accuracy of correlation between entrepreneurial orientations (proactiveness, innovativeness, and risk taking) education level of the MSMEs actors on MSMEs performance. Hypothesis assessment was determined by $\alpha<0.05$. Based on the results of this research hypothesis testing, it was proven that the entrepreneurial orientation (proactiveness, innovativeness, and risk taking) had effect on the MSMEs performance while the education level had no effect on the MSMEs performance in Bengkalis Regency. Keywords: MSMEs, proactiveness, innovativeness, risk taking, education level and performance
\end{abstract}

DOI: $10.7176 /$ RJFA/10-13-01

Publication date:July $31^{\text {st }} 2019$

\section{Introduction}

The economic development does impact the economic growth of a country. This term development is intended for the stage of developing countries, whereas the term growth is for developed countries. Indonesia is a developing country, thus it is very necessary to pay attention to the economic development from various industrial sectors, both large and small industries. In its implementation, developing countries also needs to pay more attention to Micro, Small and Medium Enterprises (MSMEs) as they have great potential and contributions to the economic development in Indonesia.

MSMEs are still the leading sector of the Indonesian economy because they are proven to be resistant to the economic crisis that hit the country, namely the monetary crisis in 1997-1998 (Sahban, 2015: 59). This crisis caused a large number of formal workers got layoff because many large companies in the formal sector were bankrupt.Since then MSMEs have a role in supporting national andregionaleconomiesfrom year to year.The existence and resilience and contribution continue to increase.No wonder the MSME sector has a strategic role in the structure of the national economy.

MSMEs generally still have very little capital and business networks.But on this small scale, MSMEs are required to be able to meet very high consumer needs. Not to mention the demand to fulfill the costumer request for goods at low prices, have high quality and stability of the available goods amount. This definitely will make MSMEs have difficulty in meeting very high consumer demand while operational and production costs, electricity tariffs and other costs are also increasingly high. Sometimes such condition triggers the failure of MSMEs to develop their businesses, even leads to bankruptcy.

In Riau Province, Bengkalis Regency is the fourth district with the most number of MSMEs, amounting to 42,029(antarariau.com). The Bengkalis Regency Governmenthas soughtto develop, empower and guide the Cooperatives and Micro, Small and Medium Enterprises that belong to the community. It is expected that the MSMEs performance can be improved.This regional government states that currently the performance of the Cooperative and MSMEs sectors are stillnot optimal in contributing to the economy in Bengkalis Regency even though the potential in Bengkalis Regency is very high (bengkaliskab.go.id).

There are a lot of things that affect business performance including those from within the entepreneur him/herself such as entepreneurial orientation (Dinesh, 2017). According to Lumpkin \& Dess (1996), entepreneurial orientation measures the extent to which company managers become more innovative, proactive and brave in taking risks.Entepreneurship is defined as anew entrythat can be done by entering a fixed or a new market with existing or new products or services, or launching a new company. Meanwhile, entepreneurial 
orientation is described as a process, practice and activity of decision makers (entepreneurial orientation) that encouragenew entry(entepreneurship).

In a dynamic environment, entepreneurial orientation is clearly very important for the survival of a business. MSMEs that have an entepreneurial orientation will tend to take actions that are proactive, innovative, and brave to take business risks in anticipating business competition and utilizing opportunities.Proactiveness reflects entepreneurial willingness to dominate competitors through a combination and aggressive moves, such as introducing new products or services in competitions and activities to anticipate future demand in order to create change and shape the environment.

Innovativeness refers to an entepreneur's attitude to be creatively involved in the trial process of new ideas that enables him/her to produce new production methods in creating new products or services, both for the current market and the future market.Besides, risk taking is an entrepreneur's attitude who has willingness to gain resources and is dare to face challenges by exploiting or engaging in business strategies where the possibility of results is full of uncertainty.In other words, MSMEs that have high entepreneurial orientation will encourage better business performance (Handari, 2015).

In addition to the entepreneurial orientation, the cause of weak MSME performance is lack of education of MSME actors.Education levelis a form of investment in the field of human resources which plays a role in spurring economic growth. This is a long-term investment because the benefits can only be felt after ten years (Utari Dan Dewi, 2014). In Bengkalis Regency the governmentcreates acontinuous education and coaching program to overcome the low level of knowledge and education of MSMEs actors (Situsriau.com).

Therefore the aim of this research is to examine to the effect of proactiveness, innovativeness, and risk taking as well education level on the SMEs performance in Bengkalis Regency.

\section{Literature Review}

\subsection{Performance}

According to Kader et al. (2009), business performance is the result that has been achieved from what has been done by the owner and / or manager in running a business. It is certain that every organization has the goals and objectives to be achieved in carrying out its missions and realizing its visions. With performance management aimed at managing a company, it is hoped that the company can achieve improved performance. Definition of performance is a quantitative and qualitative measures that describe the level of achievement of a target or goal set by an organization (Moeheriono, 2012: 32).

Lumpkin and Dess (1996) define business performance as a form commonly used to measure the impact of a company's strategic orientation. The decline in business performance is certainly a problem and is a challenge for business' strategic orientation to be able to keep maintaining business performance properly through a strategic orientation chosen based on decisions in order to survive in the industry.Company performance is an optimal work performance result,byshowing a measure of achievement obtained by a company after the company carries out a variety of corporate activities as a whole.Traditional performance measurement is a measurement of performance oriented to the financial sector and the ability to earn profits. This has led to a variety of performance measurements in the field of business research that continue to evolve on the basis of indications that varyin financial and nonfinancial terms.

Bastian (2010:137) adds that performance measurements are often seen from the profit. Profit is the best indicator to identify whether a company has done a proper action. Besides, profit is seen as one of the benchmarks of company success. Company strategy is always directed to generate company performance such as sales growth, asset growth rates and profitability. In specific, MSMEs performance measurement adopted from Lee \& Tsang (2001) regards sales growth, profit growth and capital growth.

\subsection{MSMEs}

Definition of MSMEs as regulated in Law Number 20 Year 2008 concerning Micro, Small and Medium Enterprises (MSMEs) in Chapter I (general provision) article 1 is stated as follows.

1) Micro Enterprise is a productive enterprise owned by individuals and/or individual business entities that meets the criteria of Micro Enterprise as regulated in the Law.

2) Small Enterprise is a productive economic enterprise that is independent, carried out by individuals or business entities that is not subsidiary or branch of companies owned by, controlled by, or that become part of either directly or indirectly Medium or Large Enterprises that meets the criteria of Small Enterprise as stated in the Law.

3) Medium Enterprise is a productive economic enterprise that is independent and carried out by individuals or business entities that is not subsidiary or not branch of companies owned by, controlled by, or become part of either directly or indirectly Micro, Small or Large Enterprises with the amount of net assets or annual sales.

The understandings of micro, small and medium enterprises are usually mixed, even though each of the enterprises has basic differences in terms of the criteria measurement. The following isa grouping of MSMEs based on 
enterprise criteria as well as wealth and sales results according to Law Number 20 Year 2008 Article 6.

1) Microenterprise, having a net worth of at most Rp. 50,000,000.00 (fifty million rupiah) excluding land and building for business premises or having annual sales result of a maximum of Rp. 300,000,000.00 (three hundred million rupiahs).

2) Small enterprise, having a net worth of more than Rp. 50,000,000.00 (fifty million rupiahs) up to a maximum of Rp. 500,000,000.00 (five hundred million rupiahs) excluding land and buildings for business premises or having annual sales result of more than Rp. 300,000,000.00 (three hundred million rupiahs) up to a maximum of Rp. 2,500,000,000.00 (two billion five hundred million rupiahs).

3) Medium enterprise, having a net worth of more than Rp. 500,000,000.00 (five hundred million rupiahs) up to a maximum of Rp. 10,000,000,000.00 (ten billion rupiahs) excluding land and buildings for business premises or having annual sales result of more than Rp. 2,500,000,000.00 (two billion five hundred million rupiahs) up to a maximum of Rp. 50,000,000,000.00 (fifty billion rupiahs).

\subsection{Entrepreneurial Orientation}

Entrepreneurial orientation refers to a process, practice and decision-making that push towards new inputs and has three aspects of entrepreneurship, namely innovativeness, proactiveness, and risk taking (Lumpkin and Dess, 1996). Drucker (1994) in Suherman (2008:12) explains that entrepreneurship is an ability to create something new and different.

Here are the indicators of entrepreneurial orientation as pointed out by Lumpkin and Dess (1996).

1) Proactiveness, is acting actively in detecting competitors and responding to market demand in the future. It is considered important because it implies a forward looking position along with innovative activities or new speculations. The opponent of proactiveness is passivity (inability to gain opportunities)

2) Innovativeness, is the tendency of organization management to renew their business and company willingness to enhance creativity in an effort of introducing new products.

3) Risk taking, is dare to take risks which means taking decisive actions in exploring unknown things, borrowing in large quantities and allocating significant recources to business in uncertain environments.

\subsection{Education Level}

In accordance with Law Number 20 Year 2003 concerning national education system, education level is the level of education determined by the level of student development, the goals to be achieved, and the competences to be developed. Education level is divided into two, namely formal and informal. The formal education is based on Article 14 Chapter V1, namely elementary, secondary, and tertiary education.

\subsection{Research Framework and Hypotheses}

1) The Effect of Proactiveness on the SMEs Performance

Proactiveness refers to the company's ability to take the initiative in pursuing market opportunities. Lumpkin and Dess (2001: 431) describe proactiveness as an opportunity to look forward to a perspective that involves introducing new products or services ahead of competition and taking anticipatory actions for future demands to make changes and shape the environment. Proactiveness orientation as marketers tries to define external conditions to reduce uncertainty, dependency and vulnerability.

Buli's (2017) and Dinesh's (2017) empirical studies found that proactiveness affected the performance of MSMEs. This is also supported by Sahoo and Yadav's (2017) research that found evidence that proactive behavior had a significant effect on the MSMEs performance. Another research that corroborates proactiveness relating to the performance of MSMEs had been carried out by Yun and Joo (2018) and Mamun and Fazal (2018). Based on the above explanation, the hypothesis formulated is as follows:

\section{H1: Proactiveness has a significant effect on the MSMEs Performance}

2) The Effect of Innovativeness on the MSMEs Performance

Innovativeness refers to an entrepreneur's attitude to be creatively involved in the trial process of new ideas that enables him/her to create new production methods that can produce new products or services, both for the current and new markets. An entrepreneur who successfully builds his/her business depends not only on his/her role but also on the orientation toward the organization itself, thus innovativeness orientation can help an individual to achieve the strategic goal of the organization he/she runs (Rauch et al. 2009). Success gained was through the efforts of employees in getting innovations that will advance the business so that this attitude shows that the entrepreneur has a goal, namely to improve business performance (MSMEs).

Research conducted by Sahoo dan Yadaf (2017) and Dinesh (2017) found the evidence that innovativeness had a positive effect on the MSMEs performance. In Mamun dan Fazal (2018), it was also found that innovativeness positively affected the MSMEs performance. The aforementioned explanation underlied the following hypothesis made, namely:

\section{H2: Innovativeness has a significant effect on the MSMEs performance}


3) The Effect of Risk Taking on the MSMEs Performance

Lumpkin and Dess (2001:431) point out that risk taking means a tendency to take decisive actions such as utilizing most of the resources for businesses with uncertain results. Risks in the form of the potential for circumstances that might give negative impact can happen to anyone, anywhere, anytime, including to MSMEs. Risk taking leads to behaviors that are fused and can produce adverse or dangerous decisions yet produce positive opportunities at the same time. The more perfect information is gathered, the more accurate is the risk obtained. The business goal is to get profits by increasing business performance (MSMEs).

The results of investigations done by Buli (2017), Sahoo and Yadav (2017), Dinesh (2017), as well as Mamun and Fazal (2018) proved that risk taking affected the MSMEs performance. Regarding the points above, the hypothesis was formulated as follows.

\section{H3 :Risk taking has an effect on the MSMEs Performance}

4) The Effect of Education Level on the MSMEs Performance

Education level of business actors and their labors is important in business. Education can provide knowledge to entrepreneurs to innovate and develop their business. Karadag's (2017) research revealed that the Education Level program affected the performance of MSMEs. In relation to this, the hypothesis of this research is as follows.

\section{H4 :Education level has an effect on the MSMEs performance}

\subsection{Research Model}

The following is the research model made based on the research framework that is explicated in the previous section.

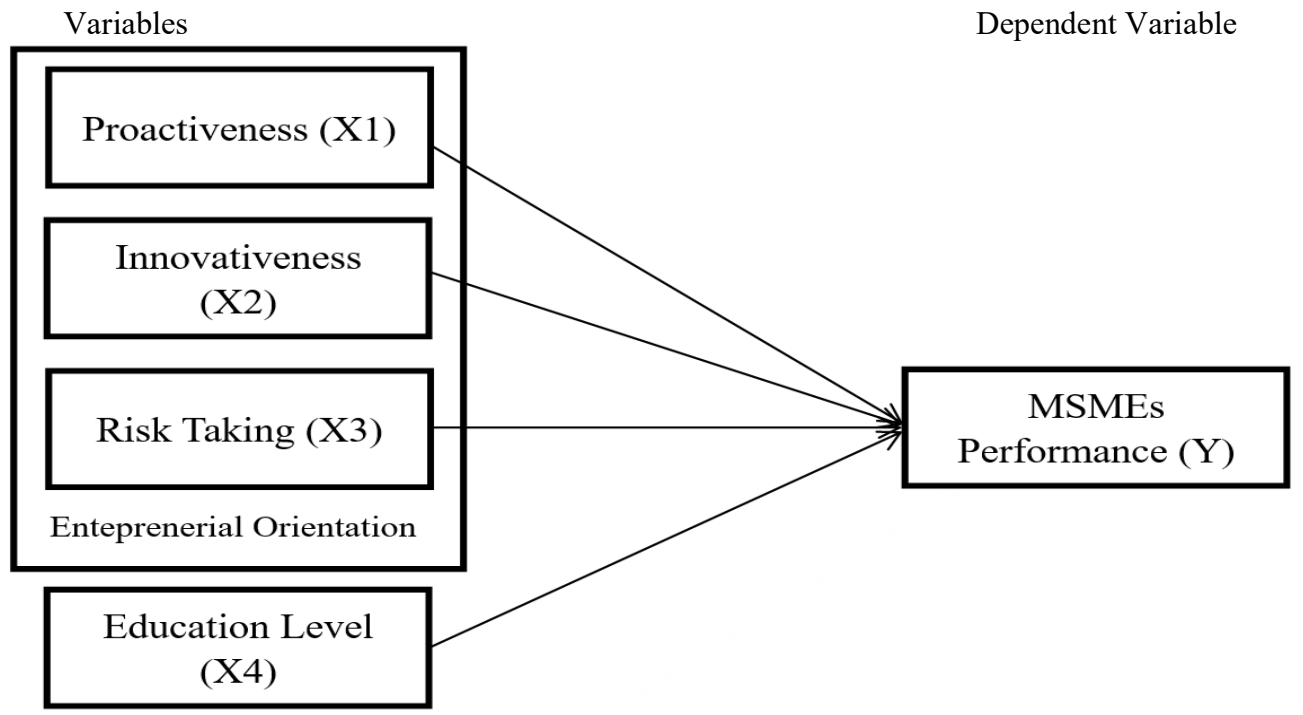

Figure 1 Research Model

\section{Research Method}

\subsection{Location and Time of Research}

This research was focused on the MSMEs in Bengkalis Regency, which is a watershed based on the Leading Research Theme and Roadmap of University of Riau 2016-2020. This research was implemented in 2019.

\subsection{Research Population and Samples}

Sugiyono (2017:80) delineates population as a generalization area consisting of objects and subjects that fulfill specific qualities and characteristics determined by researcher to be studied from which the conclusions are subsequently drawn. The population of this research was all MSMEs in Bengkalis Regency with the total number of 42,029 MSMEs.

Furthermore, according to Sugiyono (2017:81) samples are part of the number and characteristics in the population. In this research, the samples were calculated using the following Slovin formula:

$\mathrm{n}=\frac{\mathrm{N}}{1+N e^{2}}$

$\mathrm{n}=\frac{42,029}{1+\left[42,029 \times\left(0.1^{2}\right)\right.}=\frac{42,029}{421.29}=99.76$ rounded up 100 samples, 
where :

$\mathrm{N}=$ Population

$\mathrm{n}=$ Samples

$\mathrm{e}=$ Margin of error $10 \%$

Based on the above calculation, the total samples of this research were 100 MSMEs in Bengkalis Regency. The samples were chosen based on the probability sampling with simple random sampling technique, where the researchers gave the same opportunity to each of population members (MSMEs) to be chosen as a sample. This selection was conducted randomly without considering any strata in the population.

\subsection{Type and Source of Data}

The type of data collected in this research was primary data. These primary data were collected by the researchers directly from the data sources. The primary data of this research were the questionnaire answers. The source of this data was gained directly by the researchers through filling-in the questionnaire that had been distributed to all MSMEs that became the research samples.

\subsection{Technique of Data Collection}

Data collection technique applied in this research was by giving questionnaire that related to the variables being investigated.

\subsection{Operational Definitions and Variable Measurement}

1) Dependent Variable

Dependent variables one that affects or becomes the effect, due to the presence of independent variable (Sugiyono, 2017:39). The dependent variable used in this research was the MSMEs performance. Performance was the optimal work achievement carried out by individuals or groups or business entities. Traditional measurement for performance is the performance measurement that is oriented to financial sector and the ability to earn profits. The indicators used in this research were adopted from Ranto's (2016) research, namely:

a) sales growth;

b) profit growth; and

c) capital growth.

Independent variables

Proactiveness

Proactiveness is also shown as an aggressive-competitive attitude, which refers to the tendency of companies to compete strictly and directly to all of their competitors to be the best and leave their competitors behind. The success obtained through the efforts of employees to get entrepreneurial opportunities is the main source of growth and innovation for the company so that this attitude shows that entrepreneurs have a goal, namely to improve business performance (MSMEs). The proactiveness indicators used in this research were adopted from Ranto's (2016) research, namely:

- changes in market condition trigger a company to seek for positive opportunities for the company;

- companies take anticipatory actions to face future demands; and

- companies generally become the pioneer in introducing new products.

b) Innovativeness

Inovativenessrefers to an entepreneur's attitude to be creatively involved in the trial process of new ideas that enables him/her to create new production methods in order to produce new products or services, both for the current and new markets.An entepreneur who successfully builds his business depends not only on his/her role but also on the orientation toward the organization itself, thus innovativeness orientation can help an individual to achieve the strategic goals of their own organization (Rauch et al. 2009). The proactiveness indicators used in this research were adopted from Ranto's (2016)research as follows:

- looking for new ideas on his/her own;

- supporting the emergence of new product ideas;

- supporting creativity for the emergence of new products; and

- trying new business processes.

c)

$$
\text { Risk Taking }
$$

Lumpkin danDess (2001:431) define risk taking as the tendency to take decisive actions such as utilizing most of the resources for businesses with uncertain results. Risks in the form of potential event that gives a negative influence can happen to anyone, anywhere, anytime, including to MSMEs. Risk taking leads to behaviors that are fused and can produce adverse or dangerous decisions yet produce positive opportunities at the same time. The key is to get perfect information. In this research the risk taking indicators used were 
still adopted from Ranto's (2016) research as follows:

- bear the risk of unsold products;

- bear the risk of the company being closed; and

- bear the risk of financial loss.

Education Level

According to Law Number 20 Year 2003 concerning the national education system, education is defined as a consciously planned effort to create a learning atmosphere and learning process to make students actively develop their potential to have strong spiritual, self-control, personality, intelligence, noble character, and skills needed by themselves, society, and nation.

The function of national education as stated in the Law is to develop competences and to form a dignified character and national civilization in order to educate the nation's life, aiming at the development of potential students to become human beings who believe and fear the Almighty God, are noble, knowledgeable, capable, creative, independent, democratic and responsible.

In this research education was measured through four statements using Likert Scale 5 points starting from scale 1 "strongly disagree" until scale 5 "strongly agree":

- Special training is needed to support the business.

- Further education is needed to improve business performance.

- The business actors' education help run the business.

- Education is beneficial in dealing with certain problems in business.

\subsection{Data Analysis Method}

1) Descriptive Statistics

Descriptive statistics is statistics used to analyze data by describing collected data as they are without intention to make conclusions that apply to the public (Sugiyono, 2017:147). In this research, descriptive analysis was intended to provide an overview or description of the data on the dependent variable, namely the MSMEs performance, as well as the independent variables, namely variables of proactiveness, innovativeness, risk taking and education level.

2) Multiple Regression Analysis

This research applied the multiple regression to identify the accuracy of correlation between entrepreneurial orientation(proactiveness, innovativeness, and risk taking)and level of education on the MSMEs performance. Hypothesis assessment or acceptance was determined by $\alpha<0.05$. The following is the regression equation model for testing the research hypotheses:

$$
\mathrm{Y}=\alpha+\beta 1 \mathrm{X} 1+\beta 2 \mathrm{X} 2+\beta 3 \mathrm{X} 3+\beta 4 \mathrm{X} 4+\mathrm{e}
$$

$\begin{array}{ll}\text { where, } & \\ \mathrm{Y} & \text { : MSMEs performance } \\ \alpha & \text { : Constants } \\ \beta 1-\beta 4 & \text { : Coefficient of regression } \\ \mathrm{X} 1 & \text { : Proactiveness } \\ \mathrm{X} 2 & \quad \text { : Innovativeness } \\ \mathrm{X} 3 & \text { : Risk taking } \\ \mathrm{X} 4 & \text { : Level of education } \\ \mathrm{e} & \text { : Standardof error }\end{array}$

\section{Discussion}

There were total 110 questionnaire sheets distributed to the respondents and 100 questionnaire sheets were returned to the researchers.

\subsection{Respondent Characteristics}

Based on the educational background, the research found that there were $37 \%$ or 37 respondents were elementary graduates, $8 \%$ or 8 respondents were junior high school graduates, $40 \%$ or 40 respondents were senior high school graduates, and $15 \%$ or 15 respondents were graduated from bachelor program.

Meanwhile, the most favorite types of businesses of Bengkalis people were commerce with 54 respondents or the percentage of $54 \%$, followed by service sector with 32 respondents or $32 \%$, and industrial sector with 30 respondents or $30 \%$.

Relating to the the amount of omzets, there were 62 respondents or $68 \%$ that gained $<25$ million rupiahs per month, and 32 respondents or 32\% that gained $25-200$ million rupiahs per month.

4.2 Descriptive Statistics Analysis Results

The descriptive statistics analysis results can be seen as follows. 
a. Performance (Y) variable had the minimum value of 12 and the maximum value of 30 , while the mean was 20.59 and the standard deviation was 4.901 .

b. Proactiveness (X1) variable had the minimum value of 12 , the maximum value of 30 , the mean value of 19.88 and the standard deviation of 4.682 .

c. Innovativeness (X2) variable had the minimum value of 8 , the maximum value of 20 , the mean value of 12.98 and the standard deviation of 2.944 .

d. Risk taking (X3) variable had the minimum value of 8 , the maximum value of 20, the mean value of 13.26 and the standard deviation of 2.956 .

e. Education level (X4) variable variable had the minimum value of 7 , the maximum value of 20 , the mean value of 12.61 and the standard deviation of 2.554.

\subsection{Data Quality Test Results}

4.3.1 Validity Test Results

Validity test is used to measure whether a questionnaire valid or not (Ghozali, 2011). This validity test is administered by calculating correlation between item scores of instrument with the total score. The validity test results from all questions of MSMEs performance (Y), proactiveness (X1), Innovativeness(X2), risk taking (X3), and education level (X4) showed that each question item or indicator was declared "valid" because recalculate $>r$ table and the value was positive (at significance level of5\% or 0.05 ), rcalculate $>0.1965$ or sig2-tailed $0.000<0.05$. 4.3.2 Reliability Test Results

A questionnaire is declared reliable if one's answers on questions are consistent or stable from time to time. The cronbach alpha coefficient which is more than 0.60 shows the instrument reliability. Based on the reliability test results in this research, the cronbach alpha values of each variable were as follows: Performance (Y) gained 0.903, Proactiveness (X1) gained 0.908, Innovativeness (X2) gained 0.800, Risk Taking (X3) gained 0.835 and Education Level (X4) gained 0.699. All in all, all variables were declared reliable because their cronbach alpha values $>0.60$.

\subsection{Classical Assumption Test Results}

\subsubsection{Data Normality Test Results}

The normality testing is done using statistic one-sample method from Kolmogorov Smirnov (Ghozali,2013). If the significance level from from the Kolmogrov-Smirnov test is more than 0.05 , this means the data are normal. In this research the Kolmogorov-Smirnov value was 0.788 , indicating that the research data were normally distributed.

4.4.2 Multicollinearity Test Results

This multicollinearity test aims to test if in a regression model there is correlation between independent variables of research. The analysis results of this research found that the VIF values of all independent variables were $<10$ and the tolerance was $>0.10$. It can be concluded that the model regression of this research was free from the multicollinearity.

4.4.3 Heteroscedasticity Test Results

The purpose of heteroscedasticity test is to examine whether in the regression model there is any variance difference from residual of one observation to another. One way to detect heteroscedasticity is by looking at the scatterplot graph. The basic decision making is that if there is no clear pattern and the points are scattered above and below number 0 on the $Y$ axis, this means the heteroscedasticity does not occur (Ghozali, 2013: 105). The testing results of this research showed that the points were randomly scattered above and below 0 on the $\mathrm{Y}$ axis. Therefore, it was concluded that there was no occurrence of heteroscedasticity in the regression model of this research.

4.4.4 Autocorrelation Test Results

The purpose of autocorrelation test is to find out whether or not there is a correlation between variables in the prediction model with changes of time. The testing results in this research recorded that the Durbin-Watson value was 1.712 , which was between -2 and +2 . To conclude, there was no autocorrelation in this research.

4.5 Multiple Linear Regression Analysis Results

To prove if the hypotheses were accepted or rejected, the multiple linear regression test was administered. The test results are presented in Table 1 below. 
Table1 Multiple Linear Regression Analysis Results Coefficients $^{\mathrm{a}}$

\begin{tabular}{|c|c|c|c|c|c|}
\hline \multirow[t]{2}{*}{ Model } & \multicolumn{2}{|c|}{ Unstandardized Coefficients } & \multirow{2}{*}{$\frac{\text { Standardized Coefficients }}{\text { Beta }}$} & \multirow[t]{2}{*}{$\mathrm{T}$} & \multirow[t]{2}{*}{ Sig. } \\
\hline & $\mathrm{B}$ & Std. Error & & & \\
\hline (Constant) & 1.959 & 1.228 & & 1.596 & .114 \\
\hline Proactiveness & .527 & .127 & .504 & 4.139 & .000 \\
\hline 1 Innovativeness & .462 & .170 & .277 & 2.714 & .008 \\
\hline Risk Taking & .398 & .184 & .240 & 2.164 & .033 \\
\hline Education Level & -.248 & .141 & -.129 & -1.756 & .082 \\
\hline
\end{tabular}

a. Dependent Variable: the MSMEs performance Source : processed SPSS result, 2019

4.6 Discussion of Research Results

4.6.1 The Effect of Proactiveness on the MSMEs Performance

Here are the partial regression test results by comparing the value of $\operatorname{sig}<\alpha 0.05$. The proactiveness variable obtained the value of significance $0.000<\alpha 0.05$ and the multiple linear regression was 0.527 that resulted in a positive mark. This showed that proactiveness (X2) had a significantly positive effect on the MSME performance, thus H1 of this research was accepted.

Proactiveness refers to the ability of a company to take the initiative in pursuing market opportunities. Lumpkin and Dess (2001: 431) describe proactiveness as an opportunity to look forward to a perspective that involves introducing new products or services ahead of competition and taking anticipatory actions to future demands to make changes and shape the environment.

4.6.2 The Effect of Innovativeness on the MSMEs performance

Based on the partial regression test results by comparing the value of sig $<\alpha 0.05$, the innovativeness variable obtained the value of significance $0.008<\alpha 0.05$, and the multiple linear regression was 0.462 , resulting in a positive mark. This also showed that innovativeness (X2) had a significantly positive effect on the MSMEs performance. Therefore, $\mathrm{H} 2$ of this research was accepted.

Innovativeness refers to an entepreneur's attitude to be creatively involved in the trial process of new ideas which enables him/her producing new production methods to create new products or services, both for the current and new markets. An entepreneur is always eager to innovate to improve a situation. The success gained is through the efforts of employees in obtaining innovations that will advance the business so that this attitude shows the entepreneur has a goal, namely to improve his/her business performance (MSMEs).

4.6.3 The Effect of Risk Taking on the MSMEs Performance

The results of partial regression test by comparing the value of $\operatorname{sig}<\alpha 0.05$ revealed that the risk taking variable obtained the value of significance $0.033<\alpha 0.05$ with the multiple linear regression of 0.98 which resulted in a positive mark. This means that there was a significantly positive effect of risk taking (X3) on the MSMEs performance, indicating that $\mathrm{H} 3$ in this research was also accepted.

According to Lumpkin and Dess (2001: 431), risk taking means the tendency to take decisive actions such as utilizing almost the resources for businesses with uncertain results. Further, risk taking is an attitude of courage to face challenges by exploiting or engaging in business strategies where the possibility of results is full of uncertainty. The main function of the importance of entepreneurial orientation is how to involve the measurement of risk and risk taking optimally. By measuring the right risks entepreneurs will find the right decision on the risks that will be obtained so that the decision will affect the business objectives. The purpose of the business is to get profits by increasing business performance (MSMEs).

4.6.4 The Effect of Education Level on the MSMEs Performance

In this research, the results of partial regression test by comparing the value of $\operatorname{sig}<\alpha 0.05$ showed that the education level variable obtained the value of significance $0.082<\alpha 0.05$ and the multiple linear regression was $(-0.248)$ which resulted in a negative mark. This indicated that education level (X4) did not have an effect on the MSMEs performance, meaning that $\mathrm{H} 4$ of this research was rejected.

Becker (1993:29) declares that education is a process of investment activity that produces expertise (investment in human capital). The higher the human capital a person has, the higher is the ability to produce goods and services. Human capital will not arise automatically without a process of investment activities in education, both formal and informal.

4.6.5Coefficient of Determination $\left(\mathrm{R}^{2}\right)$

Analysis of determination in the multiple linear regression is used to determine the contribution percentage of the effect of independent variables simultaneously on the dependent variable. The test results recorded that the $R$ Square value was 0.784 . This means that the contribution of the effect of independent variables (proactiveness, innovativeness, risk taking and level of education) on the dependent variable (MSMEs performance) was 78.4\%, while the remaining $21.6 \%$ was affected by other variables excluded in this research model. 


\section{Closing}

5.1 Conclusion

This current research was aimed at examining the effect of proactiveness, innovativeness, risk taking and education level on the MSMEs performance in Bengkalis Regency. On the basis of the research findings and discussion, it can be concluded that proactiveness, innovativeness and risk taking had positive effects on the MSMEs performance while the level of education did not.

\subsection{Suggestions}

The following aresome suggestions for further research given by the researchers in accordance with the results, discussion, and conclusion of this current research.

1) Further research needs to enlarge the scope of samples to obtain different results.

2) Further research should add research variables which have not been used in this research to explore other possible factors that affect the MSMEs performance.

3) To deal with the limitation of this current research, further research needs to add interview method that supports researchers to get direct answers from research respondents.

\section{References}

Bastian, Indra. 2010. Akuntansi Sektor Publik Suatu Pengantar. Edisi 3. PenerbitElangga, Jakarta.

Buli, Bereket Mamo. 2017. Entepreneurial orientation, market orientation and performance of SMEs in the manufacturing industry: Evidence from Ethiopian enterprises. Journal of Management Research Review, Vol. 40 Issue: 3, pp.292-309

Dinesh, Siwa. 2017. Pengaruh Orientasi Kewirausahan, Lingkungan Bisnis dan Kemampuan Manajemen terhadap Kinerja Usaha UMKM Kuliner di Pagaruyung Medan. Skripsi Universitas Sumatera Utara. Medan.

Ghozali, Imam. 2011. Structural Equation Modelling MetodeAlternatifdengan Partial Least Square, Edisi 3. BadanPenerbitUniversitasDiponegoro. Semarang.

Handari, Sri dan Isthofaina Astuty. 2015. Analisis Peningkatan Kinerja UMKMDitinjau dari Orientasi Kewirausahaan dalam Meningkatkan Efektifitas Program Corporate Social Responsibility (Studi pada UMKM Binaan PT Bank Bri dan Bank Indonesia). Jurnal Universitas Muhammadiyah Yogyakarta.

Kader, et al. 2009. Success factors for small rural entepreneurs under the one-district-one-industry programme in Malaysia,Contemporary Management Research, 5(2), 147-162.

Karadag, Hande. 2017. The impact of industry, firm age and education level on financial management performance in small and medium-sized enterprises (SMEs): Evidence from Turkey). Journal of Entepreneurship in Emerging Economies, Vol. 9 Issue: 3, pp.300-314

Lee, D.Y \& Tsang E.W.K. 2001. The Effect OfEntepreneurial Personality, Background And Network Activities On Venture Growth, Journal of Management Studies.

Lumpkin, G.T. dan Gregory G. Dess. 1996. Clarifying The EntepreneurialOrientation Construct and Linking it To Performance. Jurnal Academy ofManagement Volume 21. No. 1. Hal. 135-172.

Mamun, Abdullah Al dan Syed Ali Fazal. 2018. Effect of Entepreneurial Orientation on Competency and microentreprise performance,Asia Pacific Journal and Entepreneurship, Vol. 12 Issue:3, pp.379-390Malaysia Kelantan University.

Moeheriono. 2012. Pengukuran Kinerja Berbasis Kompetensi. Penerbit Raja Grafindo Persada. Jakarta.

Ranto, DwiWahyuPril. 2016. PengaruhOrientasiKewirausahaanTerhadap Kinerja UMKM BidangKuliner di Yogyakarta.JurnalJBMA - Vol. III, No. 2.

Rauch, Andreas. Et. Al. 2009. Entepreneurial Orientation AndBusinessPerformance: An Assessment Of Past Research And Suggestions For The Future. Journals researchgate.

Sahban, Hernita. 2015. MenembusBadai UMKM. Penerbit CV Sah Media, Makasar.

Sahoo, Saumyaran jandan Shudir Yadav. 2017. Entepreneurial orientation of SMEs, total quality management and firm performance. Journal of Manufacturing Technology Management Vol. 28 Issue: 7, pp.892-912

Sugiyono, 2017.Metode PenelitianKuantitatif, Kualitatifdan R\&D. Edisi 25, PenerbitAlfabeta, Bandung. Suherman, Eman. 2008. Business Entepreneur. PenerbitAlfabeta,Bandung.

Undang-Undang Republik Indonesia Nomor 20 Tahun 2003 Tentang Sistem Pendidikan Nasional.

Undang-Undang Republik Indonesia Nomor 20 Tahun 2008 Tentang UsahaMikro, Kecil, dan Menengah.

Yun, Hee Cho danJooHeon Lee. 2018. Entepreneurial Orientation, Entepreneurial Education and Performance,Asia Pacific Journal and Entepreneurship, Vol. 12 Issue:3, pp.124-134Yonsei University. South Korea

https://www.antarariau.com/berita/80571/jumlah-umkm-di-pekanbaru mencapai 67728, 10 Oktober 2018.

https://bengkaliskab.go.id/berita-diskop-umkm-lakukan-pembinaan bengkalis.html, 9 Januari 2019

kepadakoperasi-dan-usaha-di- 